\title{
PHYSIOLOGICAL CHARACTERIZATION OF Rosellinia bunodes AND SYMPTOMATOLOGY OF Rosellinia ROOT ROT IN POPLAR SEEDLINGS ${ }^{1}$
}

\author{
Heloisa Thomazi Kleina ${ }^{2 *}$, Álvaro Figueredo dos Santos ${ }^{3}$, Henrique da Silva Silveira Duarte ${ }^{2}$ and Edilene \\ Buturi Machado ${ }^{4}$ \\ ${ }^{1}$ Received on 19.12.2017 accepted for publication on 05.01.2018. \\ ${ }^{2}$ Universidade Federal do Paraná, Departamento de Fitotecnia e Fitossanidade, Curitiba, Paraná - Brasil. E-mail: \\ $<$ helloisathomazi@hotmail.com>and <henriqueduarte@ufpr.br>.. \\ ${ }^{3}$ Empresa Brasileira de Pesquisa Agropecuária, Centro Nacional de Pesquisa de Florestas, Colombo, PR - Brasil. E-mail: \\ <alvaro.santos@embrapa.br>. \\ ${ }^{4}$ Universidade Federal do Paraná, Departamento de Ciências Florestais, Curitiba, Paraná, Brasil. E-mail: \\ <edilene.machado@swedishmatch.com.br>. \\ *Corresponding author.
}

\begin{abstract}
Poplar (Populus deltoides) is a forest species that has several phytosanitary problems, such as leaf spots, rusts and root rots. Since 2010 , the death of poplar trees has been observed in commercial plantations in the state of Paraná, Brazil, caused by the fungus Rosellinia bunodes. Due to the lack of information about this pathosystem, the aim of this work was to carry out the physiological characterization of $R$. bunodes isolates collected from $P$. deltoides and the symptomatological characterization of Rosellinia root rot in the same host. Experiments were conducted at Embrapa Florestas, located in Colombo (PR), Brazil. The mycelial growth of nine $R$. bunodes isolates was evaluated in four culture media (potato-dextrose-agar, V8agar, carrot-agar and water-agar) and seven different incubation temperatures $(8,12,16,2024,28$ and 32 ${ }^{\circ} \mathrm{C}$ ). The symptomatological characterization of Rosellinia root rot was performed on six-month-old poplar seedlings. The most favorable conditions for mycelial growth of $R$. bunodes were observed in potato dextrose agar (PDA) at $24^{\circ} \mathrm{C}$. The symptoms and signs of the disease internally in the stem showed up at 7 days after inoculation (DAI); however, chlorosis and wilting were observed only at 14 DAI. Sexual and asexual reproductive structures of $R$. bunodes were not observed on inoculated plants.
\end{abstract}

Keywords: Root rot; Fungus; Mycelial growth.

\section{CARACTERIZAÇÃO FISIOLÓGICA DE ROSELLINIA BUNODES E SINTOMATOLÓGICA DA ROSELINIOSE EM ÁLAMO}

\begin{abstract}
RESUMO-O álamo (Populus deltoides) é uma espécie florestal que possui diversos problemas fitossanitários, como a ocorrência de manchas foliares, ferrugens e podridões radiculares. Desde 2010 tem-se verificado a morte de árvores em plantios comerciais no estado do Paraná, Brasil, ocasionados pelo fungo Rosellinia bunodes. Devido a carência de informações sobre este patossistema, objetivou-se com esse trabalho, realizar a caracterização fisiológica de isolados de R. bunodes e sintomatológica da roseliniose em álamo. Os experimentos foram conduzidos na Embrapa Florestas, localizada no município de Colombo (PR), Brasil. O crescimento micelial de nove isolados de R. bunodes foi avaliado em quatro meios de cultura (batata-dextrose-ágar, V8ágar, cenoura-ágar é ágar-água) e sete temperaturas $\left(8,12,16,20,24,28\right.$ e $\left.32^{\circ} \mathrm{C}\right)$. A caracterização sintomatológica da roseliniose foi realizada em mudas de álamo, com aproximadamente seis meses de idade. As condições mais favoráveis ao crescimento micelial de $\mathrm{R}$. bunodes foram observadas no meio de cultura batata-dextroseágar (BDA) a temperatura de $24^{\circ} \mathrm{C}$. Os sintomas e sinais do patógeno internamente ao caule mostraramse aparentes aos 7 dias após a inoculação (DAI); por outro lado, os sintomas de clorose associada a murcha tornaram-se visiveis apenas aos 14 DAI. Não foram observadas estruturas reprodutivas sexuadas e assexuadas de R. bunodes nas plantas inoculadas.
\end{abstract}

Palavras-Chave: Podridão radicular; Fungo; Crescimento Micelial.

Revista Árvore. 2018;42(1):e420111 


\section{INTRODUCTION}

Poplar (Populus deltoides Bart. ex Marsh.) is a forest species originating from the Eastern region of North America and stands out for having a light and resistant wood, which adds high economic value in the manufacture of matchsticks (Santos and Machado, 2010; May-De Mio and Amorim, 2005) and the furniture industry. In Brazil, commercial plantations are located in the region of Vale do Iguaçu (states of Paraná and Santa Catarina) (May-De Mio and Amorim, 2005), covering 4,216 hectares (Indústria Brasileira de Árvores, 2017).

Because it is an exotic species, poplar clones face several phytosanitary problems in Brazil. The most frequently occurring diseases are rust (Melampsora medusae Thuem.) (Santos and Machado, 2010; MayDe Mio and Ruaro, 2008) and septoria leaf spot (Septoria musiva Peck.) (Santos et al., 2010). However, since 2010 , the appearance of root rot with the presence of dense mycelial growth, chlorosis and widespread wilt of leaves has been observed, followed by death of trees in poplar plantations in the state of Paraná, caused by Rosellinia root rot (Rosellinia bunodes) (Santos et al., 2017).

Rosellinia bunodes (Berk \& Broome) Sacc. (Class Sordariomycetes; Order Xylariales; Family Xylariaceae) is a fungus capable of infecting a wide range of hosts (Castro et al., 2013), including woody species (PérezJiménez, 2006), although it has also been reported in bulbs (Narcissus spp.) (Mantell and Wheeler, 1973) and rhizomes (Zingiber officinale) (Smith, 1929). In addition, it may saprophytically survive in the mycelial form under dead parts of the host (May-De Mio et al., 2016). This species has a more generalized distribution when compared to other species of the same genus, occurring mainly in the Americas, Africa, India, Indonesia, the Philippines and Sri Lanka (Holliday, 1980; Petrini, 1993). The pathogen is favored by the presence of stumps with roots under decomposition process due to the organic matter content in the soil surface and by continuous and frequent rains, being detected higher incidence of the disease in areas with high rainfall and low luminosity (Oliveira, 1992).

Rosellinia bunodes produces smooth and dark perithecia containing single-celled ascospores (Hoopen and Krauss, 2006). Asexual reproduction occurs through conidia, described as Dematophora sp. (Sivanesan and Holliday, 1972). The hyphae of this fungus present in the form of piriform swells in the septa, common to the genus Rosellinia (Sztejnberg et al., 1980), which can aggregate, forming rhizomorphs (Castaño, 1953).

In Brazil, the genus Rosellinia has been reported in Araucaria (Araucaria angustifolia) (Auer and Grigoletti, 1997), mate tea (Ilex paraguariensis) (Grigoletti and Auer, 1996) and cacao (Theobroma cacao L.) (Oliveira, 1981). In Araucaria, it is possible to observe the signs of the pathogen located in the roots and the base of the trunk of trees, presenting in the form of a whitish mycelium that, with the advance of colonization, becomes blackened due to the formation of fruiting bodies. External symptoms, such as generalized chlorosis, wilt and drying manifest only when the host's root system is colonized by the pathogen (Ferreira, 1989). Rosellinia root rot can manifest at any stage of plant development, and can attack both young seedlings and adult trees in full production. In cocoa plantations (Theobroma cacao L.), the occurrence of $R$. pepo and $R$. bunodes was observed in plants with approximately eight months of age in replanting areas, where the removal of organic material and cultural remains was not carried out during the eradication of dead plants (Oliveira and Luz, 2005).

Knowledge about the conditions that favor fungal mycelial growth are very important in phytopathological studies, as in the evaluation of resistance of fungi to fungicides; in the potential of biological control agents applied to pathogens, in tests of the efficiency of phytosanitary products and in the identification of fungi through the characteristics of their colonies. For this, artificial culture media should simulate the natural environmental conditions, containing nutrients in adequate proportions for the maintenance and multiplication of microorganisms (Dhingra and Sinclair, 1995). Temperature is another important factor for the mycelial growth of $R$. bunodes. Microorganisms develop in temperature ranging from minimum starting temperature, optimum growth temperature and maximum temperature, since optimum temperature can vary within the species and between isolates of the same species, allowing fungi to express their maximum metabolic potential.

Studies including symptom characterization can serve as a basis for the correct diagnosis of diseases, based on the manifestation of the plant reactions to a harmful agent (symptoms) and on the appearance of pathogen structures externalized in the diseased

Revista Árvore. 2018;42(1):e420111

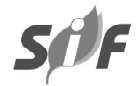


tissue (signs), aiding future development and recommendation of more efficient control strategies. Thus, the aim of this work was to perform the physiological and symptomatological characterization of the Rosellinia root rot pathosystem in poplar.

\section{MATERIALAND METHODS}

\subsection{Obtaining isolates}

Experiments were conducted at the Laboratory of Forest Pathology of the Brazilian Agricultural Research Company (Embrapa Florestas), located in the municipality of Colombo (PR), Brazil, from October 2013 to October 2014.

$R$. bunodes isolates were obtained from the collection of the Laboratory of Forest Pathology of Embrapa Florestas. Nine R. bunodes isolates (R1, R2, R3, R3A, R4, R5, R6, R7 and R8) were used, all of them from poplar root isolates with root rot symptoms collected at commercial plantations in the municipality of Paula Freitas (PR), Brazil. Each isolate was collected from distinct trees along each planting plot. The distance from each collection point ranged from 300 to $2000 \mathrm{~m}$.

\subsection{Physiological characterization of $R$. bunodes}

The physiological characterization of $R$. bunodes isolates was performed by evaluating the mycelial growth of $R$. bunodes in four culture media and six temperatures in two experiments.

To evaluate the mycelial growth of $R$. bunodes in different culture media, an experiment was conducted in a completely randomized design in a $9 \times 4$ factorial scheme ( 9 isolates $\times 4$ culture media) with 3 replicates, each replicate being composed of a Petri dish $(90 \mathrm{~mm}$ diameter). The four culture media used were: a) potatodextrose-agar (PDA) (39 g of powdered PDA, 1 L of distilled water); b) V8-agar (200 ml of V8-agar juice, $4 \mathrm{~g}$ of $\mathrm{CaCO}_{3}, 18 \mathrm{~g}$ of agar and $800 \mathrm{ml}$ of distilled water); c) carrot-agar (CA) (200 g of carrot scraped and cut into slices, $500 \mathrm{ml}$ of distilled water) and d) agar-water (AW) (20 g bacteriological agar, $1 \mathrm{~L}$ distilled water). All media were autoclaved at $120{ }^{\circ} \mathrm{C}$ for 30 minutes and poured into Petri dishes. Disks of $5 \mathrm{~mm}$ in diameter of the nine $R$. bunodes isolates were peeled and deposited at the center of each Petri dish. Petri dishes were maintained in a BOD-like growth chamber at $24^{\circ} \mathrm{C}$ under continuous darkness for a period of 7 days. Evaluation consisted in the measurement of two diametrically opposed measures with the aid of a digital caliper every two days, from the third to the seventh day after the experiment installation. The homogeneity of data variance was verified by the Bartlett test and the error normality by the Kolmogorov-Smirnov test. Data were submitted to analysis of variance by the $\mathrm{F}$ test and when significant, they were compared by the Tukey test ( $5 \%$ significance). Statistical analyses were performed through the ASSISTAT 7.7 beta program (Silva and Azevedo, 2002).

To evaluate mycelial growth of $R$. bunodes at different temperature ranges, a completely randomized design experiment was conducted using 7 treatments and 3 replicates, each replicate being composed of three Petri dishes ( $90 \mathrm{~mm}$ diameter) per isolate for each temperature. The temperatures evaluated were: 8,12 , $16,20,24,28$ and $32^{\circ} \mathrm{C}$. PDA disks of $5 \mathrm{~mm}$ in diameter (medium chosen from results obtained in the first assay) with active mycelial growth of each of the nine $R$. bunodes isolates were placed at the center of Petri dishes containing the same culture medium and incubated in a continuous dark BOD-type growth chamber under different temperatures. The evaluation of the mycelial growth consisted in the measurement of two diametrically opposite measures with the aid of a digital caliper every two days, from the third to the seventh day after experiment installation. Data were submitted to descriptive statistical analysis to verify the optimal temperature for the mycelial growth of $R$. bunodes.

\subsection{Symptomatological characterization of Rosellinia root rot in inoculated poplar seedlings}

For the characterization of the disease symptomatology, inoculation of 25 plants cultivated in substrate infested with the pathogen was carried out. Control consisted of 5 healthy poplar seedlings that did not receive the inoculum. For the inoculum production, $80 \mathrm{~g}$ of sorghum grains were added with $40 \mathrm{~mL}$ of distilled water in clear glass vials of $500 \mathrm{~mL}$ (14.5 $\mathrm{cm}$ in height and $5 \mathrm{~cm}$ in diameter) and then autoclaved at $120^{\circ} \mathrm{C}$ for 30 minutes. Then, each flask was added of 7 disks with $8 \mathrm{~mm}$ in diameter of PDA culture medium with active mycelial growth of $R$. bunodes $\mathrm{R} 2$ isolate, which in previous tests demonstrated rapid growth in culture medium and increased aggressiveness when inoculated in different plant hosts. The material was incubated at $24^{\circ} \mathrm{C}$ in the dark for 17 days. Daily, flasks were hand shaken for better distribution of disks and uniformity of mycelial growth in sorghum grains. 
After 17 days of incubation, commercial substrate (Plantmax Florestal ${ }^{\circledR}$ ) was mixed in the proportion of $1 \mathrm{~kg}$ of substrate to $32 \mathrm{~g}$ of sorghum grains colonized with the fungus to obtain the infested substrate. Inoculation was carried out by placing the infested substrate in 25 plastic pots with capacity of $1.7 \mathrm{~L}$ (height: $20 \mathrm{~cm}$, diameter: $12 \mathrm{~cm}$ ), and then 1 poplar seedling (Populus deltoides) of clonal origin with six months was transplanted in each pot.

Seedlings were kept in greenhouse with average temperature of $26.7^{\circ} \mathrm{C}$, ranging from 21 to $31^{\circ} \mathrm{C}$ throughout the experiment, being measured with the aid of a conventional thermometer. Irrigation was daily performed using a hand irrigator.

During five weeks, weekly analyses of external incidence $(\%)$, internal incidence (\%) and internal severity (\%) were performed on poplar seedlings inoculated with $R$. bunodes. For the evaluation of external incidence, the number of plants with symptoms in the aerial part, which were characterized by the appearance of chlorosis associated with wilt, was counted. In this analysis, evaluations began with a group of 25 plants at the time of experiment implementation and were reduced in number of 5 at each evaluation date due to weekly destructive analyses of internal incidence and severity. For the quantification of internal incidence and severity, 5 arbitrarily selected seedlings had the substrate removed and were submitted to longitudinal cuts in areas near the collar. The internal incidence analysis considered the presence or absence of root darkening and vascular bundles. The internal severity variable considered the percentage or proportion of injured plant area (darkening) in stem structures due to the growth of $R$. bunodes. Severity was determined by photographing collar fragments with a digital camera and analyzed using the Quant software (Vale et al., 2003).

To verify the morphological structures of the pathogen formed in inoculated plants, microscopic slides $(25.4 \times 76.2 \mathrm{~mm})$ were prepared from root fragments of poplar seedlings containing signs of $R$. bunodes. Small portions of fungal mycelium inside the shell were scraped and deposited at the center of slides with the help of a previously sterilized blade. Subsequently, the assembly liquid (methylene blue) was added, and the cover slip was removed, excess dye was removed with soft tissue paper. Slides were sealed with colorless enamel and visualized under Olympus CH30 optical microscope, in 40x magnification.

\section{RESULTS}

\subsection{Physiological characterization of $R$. bunodes}

The four culture media tested provided mycelial growth of $R$. bunodes. However, significant differences were observed among isolates and culture media used. The highest mycelial growth occurred in PDA medium for all isolates. For V8-agar medium, R7 and R8 R. bunodes isolates showed lower growth when compared to the others. In CA medium, the highest mycelial growth of R2, R3, R3A, R5 and R6 isolates was favored, and in the AW medium, all isolates showed the lowest mycelial growth, compared to other media tested (Table 1). The youngest $R$. bunodes colonies stood out for having white cotonous coloration in all tested culture media, becoming predominantly brown as the mycelium aged.

In the mycelial growth experiment at different temperatures, the highest mycelial growth values were recorded at $24^{\circ} \mathrm{C}$ for all isolates evaluated (Figure 1).

\subsection{Symptomatological characterization of Rosellinia root rot in poplar seedlings}

The internal disease incidence was $100 \%$ at 7 days after inoculation (DAI) (Figure 2), showing that in this period, all plants presented symptoms of darkening of vascular bundles. In this period, no symptoms were observed in the aerial part, although the mean internal

Table 1 - Colony diameter ( $\mathrm{mm}$ ) of nine isolates of Rosellinia bunodes grown on different culture media. Colombo (PR), Brazil, 2013.

Tabela 1 - Diâmetro $(\mathrm{mm})$ de colônias de nove isolados de Rosellinia bunodes cultivados em diferentes meios de cultura. Colombo (PR), Brasil, 2013.

\begin{tabular}{ccccc}
\hline \multirow{5}{*}{$\begin{array}{c}\text { bunodes } \\
\text { isolates }\end{array}$} & \multicolumn{4}{c}{ CULTURE MEDIA** } \\
\cline { 2 - 5 } & PDA & V8-agar & CA & AW \\
\hline R1 & $82.6 * \mathrm{aA}$ & $79.9 \mathrm{abA}$ & $56.8 \mathrm{cB}$ & $22.0 \mathrm{bC}$ \\
R2 & $90.0 \mathrm{aA}$ & $90.0 \mathrm{aA}$ & $83.0 \mathrm{abA}$ & $31.6 \mathrm{abB}$ \\
R3 & $90.0 \mathrm{aA}$ & $90.0 \mathrm{aA}$ & $90.0 \mathrm{aA}$ & $37.5 \mathrm{abB}$ \\
R3A & $90.0 \mathrm{aA}$ & $90.0 \mathrm{aA}$ & $90.0 \mathrm{aA}$ & $42.1 \mathrm{aB}$ \\
R4 & $90.0 \mathrm{aA}$ & $90.0 \mathrm{aA}$ & $69.7 \mathrm{bcB}$ & $33.7 \mathrm{abC}$ \\
R5 & $90.0 \mathrm{aA}$ & $90.0 \mathrm{aA}$ & $90.0 \mathrm{aA}$ & $28.1 \mathrm{abB}$ \\
R6 & $90.0 \mathrm{aA}$ & $90.0 \mathrm{aA}$ & $90.0 \mathrm{aA}$ & $32.4 \mathrm{abB}$ \\
R7 & $90.0 \mathrm{aA}$ & $71.7 \mathrm{bB}$ & $66.3 \mathrm{bcB}$ & $36.4 \mathrm{abC}$ \\
R8 & $84.6 \mathrm{aA}$ & $65.2 \mathrm{bB}$ & $52.5 \mathrm{cB}$ & $32.5 \mathrm{abC}$ \\
\hline CV $\%)$ & \multicolumn{5}{c}{9.60} \\
\hline
\end{tabular}

Averages followed by uppercase letters in the row and lowercase letters in the column differ statistically by the Tukey test at $5 \%$ probability; Culture media: PDA: potato-dextrose-agar; CA: carrot-agar; AW: agar-water; CV: coefficient of variation

Revista Árvore. 2018;42(1):e420111 
severity was $45.1 \%$ (Figure 2 and Figures $3 \mathrm{~A}$ and B). Only from 14 DAI (Figures 2 and 3 C), plants begun to present symptoms of chlorosis associated with wilt, with average external incidence of $5 \%$. At $21 \mathrm{DAI}$, the average external incidence was $86.6 \%$. From this period, dry branches and leaf fall were observed, culminating in the death of seedlings (Figures 2 and $3 \mathrm{D}, \mathrm{E}$ and F). When performing the longitudinal cut in areas near the collar, wood tissues showed pigmentation ranging from light brown to black (Figures $2 \mathrm{~B}$ and F), which characterizes the internal symptoms of the disease.

In the basal region of seedlings, in roots and adjacent soil, the development of mycelium and whitish rhizomorphs (Figures $4 \mathrm{~B}$ and C) was observed at 7 DAI (Figure 4 D). Over time, lesions became blackened, the main characteristic of this rot. Under the microscope, pyriform swells were observed at the base of the hyphae septa (Figure 4A). No perithecia, conidiophores and fungal conidia were observed.

\section{DISCUSSION}

Rosellinia root rot in poplar is a new pathosystem in the country, so there is no information on the physiological characterization of the pathogen and the manifestation of symptoms. With this work, it was possible to determine the ideal conditions of $R$. bunodes growth in culture medium, as well as to know the symptomatology of the disease through inoculation under controlled conditions, confirming the importance of this pathogen to the Brazilian edaphoclimatic conditions.

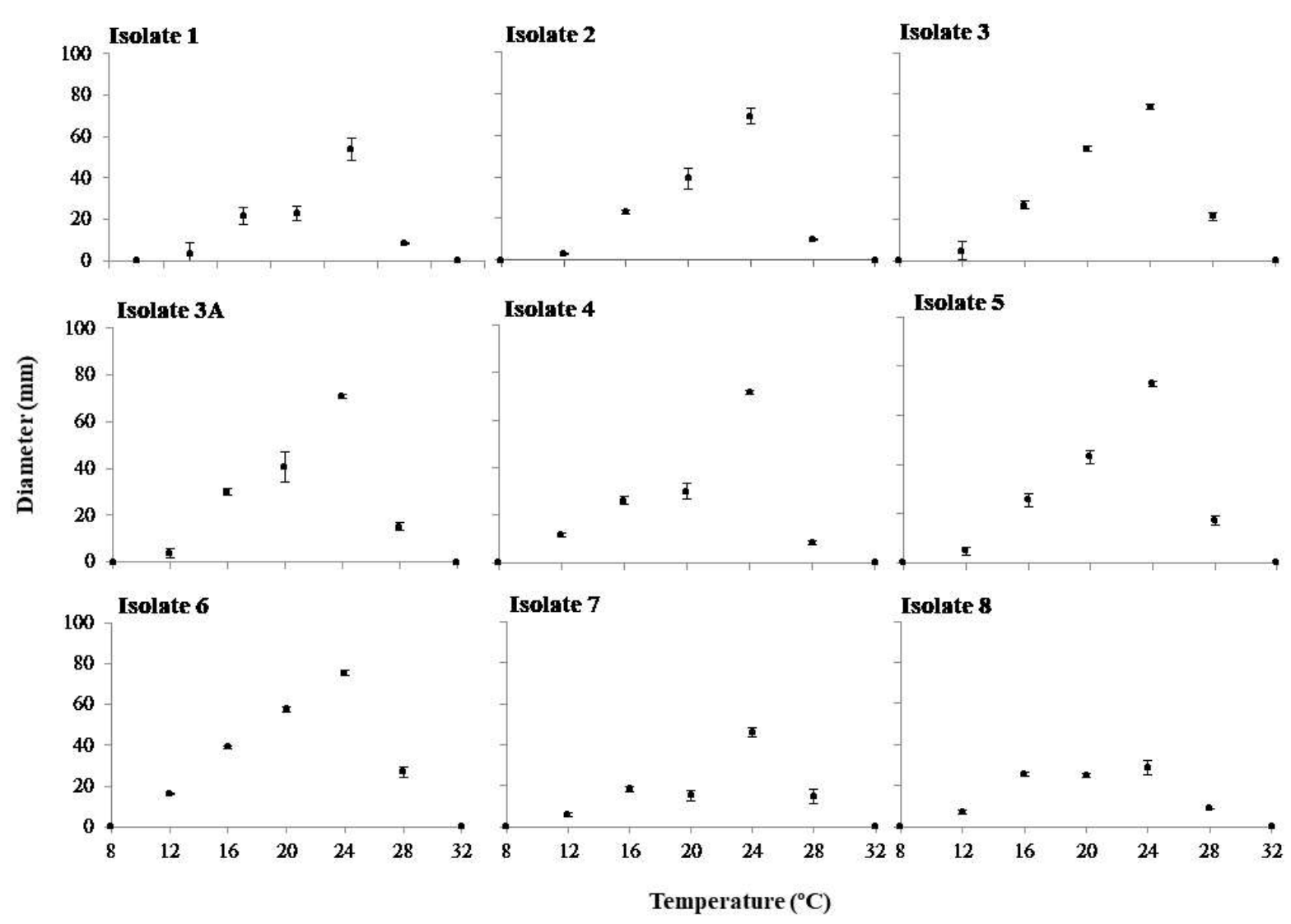

Figure 1 - Mycelial growth (mm) of nine isolates of Rosellinia bunodes at seven different temperatures $(8,12,16,20$, 24,28 and $32{ }^{\circ} \mathrm{C}$ ). The bars represent standard deviations. Colombo (PR), Brazil, 2013.

Figura 1 -Crescimento micelial $(\mathrm{mm})$ de nove isolados de Rosellinia bunodes em sete diferentes temperaturas $(8,12,16$, 20, 24, 28 e $32^{\circ} \mathrm{C}$ ). As barras representam o desvio padrão. Colombo (PR), Brasil, 2013. 


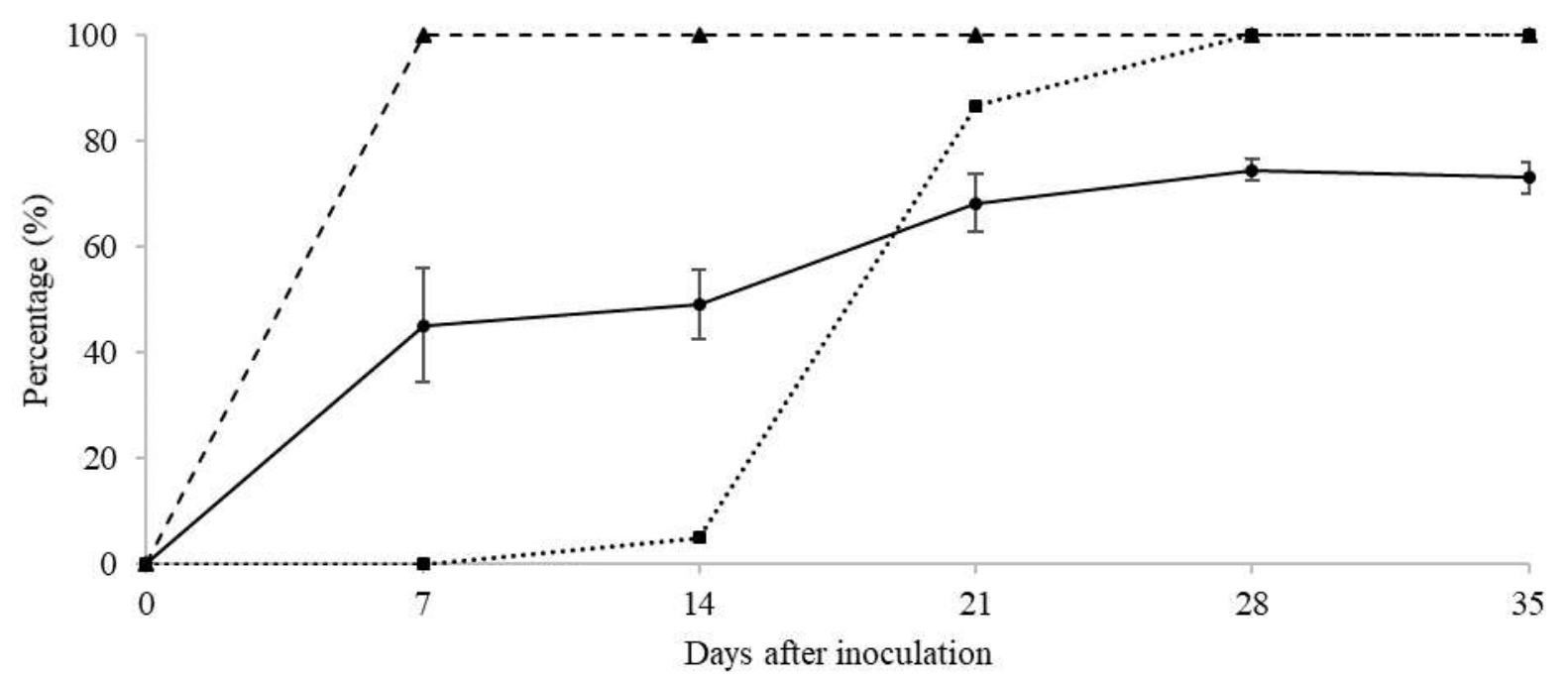

$\longrightarrow$ Severity $\quad \cdots . \cdots$ External incidence $\quad--\downarrow-$ Internal incidence

Figure 2 - External incidence, internal incidence and internal severity (percentage data) of Rosellinia root rot in poplar seedlings after inoculation with R2 isolate of Rosellinia bunodes. The bars represent the standard error of the mean. Colombo (PR), Brazil, 2014.

Figura 2 - Incidência externa, incidência interna e severidade interna (dados em porcentagem) de roseliniose em mudas de álamo após a inoculação com o isolado R2 de Rosellinia bunodes. As barras representam o erro padrão da média. Colombo (PR), Brasil, 2014.

The culture medium composition affects the quantity and quality of growth and sporulation of phytopathogenic fungi (Dhingra and Sinclair, 1995). The PDA medium provided the best mycelial growth conditions for all $R$. bunodes isolates tested, corroborating Bermudez and Carranza-Morse (1992), who found that the growth of $R$. bunodes (Coffea arabica and Alnus acuminata isolates) in PDA medium was superior in relation to agar-water medium, malt-agar extract, vegetable juice with agar and without agar (V-8), maize-agar extract and macerated coffee agar root extract. In contrast, the AW culture medium did not favor the development of $R$. bunodes. V8-agar and CA media presented satisfactory performance in relation to the mycelial growth of $R$. bunodes, exhibiting considerably high diameter values for R2, R3, R3A, R4, R5, R6 and R7 isolates. This fact confirms the information provided by Moore-Landecker (1996), who reported that media with high concentration of carbohydrates stimulate the mycelial growth of numerous fungi. Dhingra and Sinclair (1995) also claim that media containing decocts, extracts and juices from leaves or plant parts promote the mycelial growth of a wide range of fungi.
The temperature of $24^{\circ} \mathrm{C}$ was ideal for the mycelial growth of $R$. bunodes in different temperature ranges. Ruano-Rosa et al. (2003) in a study on the thermal conditions suitable for the in vitro $R$. necatrix growth confirmed that the ideal growth temperature for this species was $25^{\circ} \mathrm{C}$. For Bermúdez and Carranza-Morse (1992), the temperature of $27^{\circ} \mathrm{C}$ was the most efficient for the vegetative growth of $R$. bunodes in PDA medium. Infective processes are also directly influenced by temperature (RIVERA, 1940). This author reported that the infection of younger roots of specific vine cultivars by $R$. necatrix was complete 24 hours after experimental inoculation at $25^{\circ} \mathrm{C}$, but at $8{ }^{\circ} \mathrm{C}$, absence of infection was observed. Rivera (1940) also did not observe mycelial growth of $R$. necatrix at $8^{\circ} \mathrm{C}$, although the fungus was still viable, reinforcing the results obtained in this experiment. For the temperature of $20{ }^{\circ} \mathrm{C}$, satisfactory mycelial growth was observed, confirming the information contained in the works of Duque (1951) and López-Duque and Fernández (1966). For these authors, temperatures between 20 and $23{ }^{\circ} \mathrm{C}$ are considered ideal for the development of $R$. bunodes and R. pepo. A noticeable decrease

Revista Árvore. 2018;42(1):e420111 


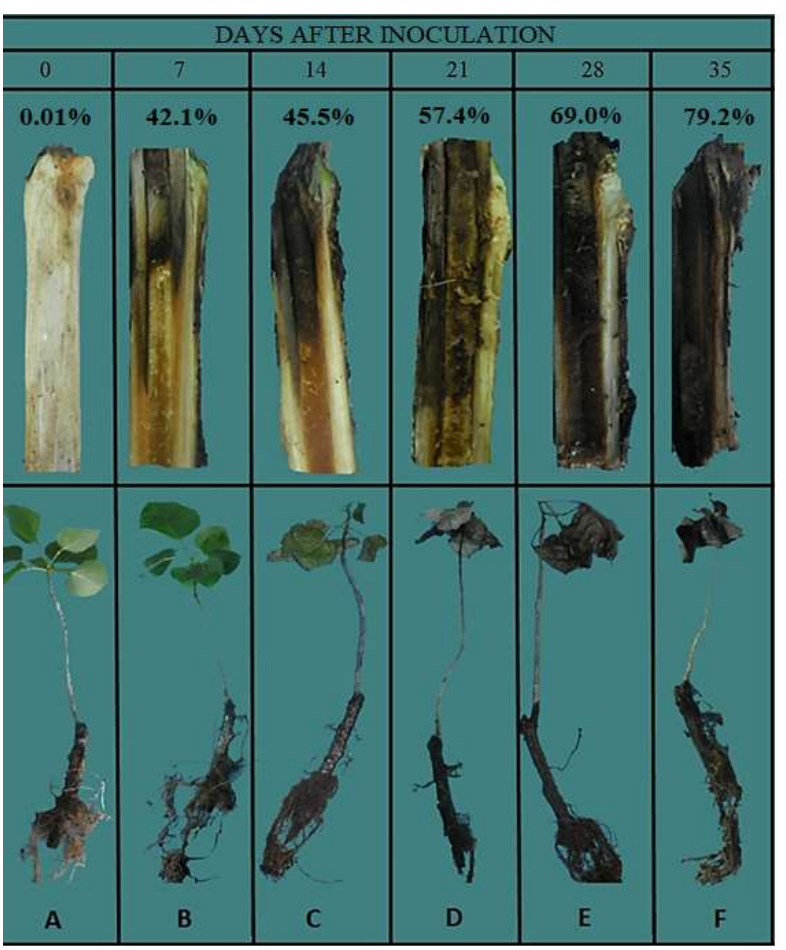

Figure 3 - Symptomatology of Rosellinia root rot in poplar seedlings. The upper part of the figure are presented the longitudinal cuts of areas near the stem collar, and bottom images are respectively photos of the whole plant. A) control: healthy seedling with $0 \%$ of severity; B) seedling at 7 days after the inoculation with $9.41 \%$ severity; C) seedling at 14 days after inoculation with $30.22 \%$ severity; D) seedling at 21 days after inoculation with $48.29 \%$ severity; E) seedling at 28 days after inoculation with $69 \%$ severity; F) seedling at 35 days after inoculation with 79.2\% severity. Colombo (PR), Brazil, 2014.

Figura 3-Sintomatologia da roseliniose em mudas de álamo. Na parte superior da figura estão apresentados os cortes longitudinais em áreas próximas ao colo, e nas imagens inferiores estão as respectivas fotos da planta inteira. A) testemunha: muda sadia com $0 \%$ de severidade; B) muda aos 7 dias após a inoculação com 9,41\% de severidade; C) muda aos 14 dias após a inoculação com 30,22\% de severidade; D) muda aos 21 dias após a inoculação com 48,29\% de severidade; E) muda aos 28 dias após a inoculação com $69 \%$ de severidade; $F$ ) muda aos 35 dias após a inoculação com $79,2 \%$ de severidade. Colombo (PR), Brasil, 2014.

in $R$. bunodes growth was observed at temperatures above $30{ }^{\circ} \mathrm{C}$ and no growth was observed above 35 ${ }^{\circ} \mathrm{C}$ (Bermúdez and Carranza-Morse, 1992), as observed in dishes maintained at $32^{\circ} \mathrm{C}$ in this work.
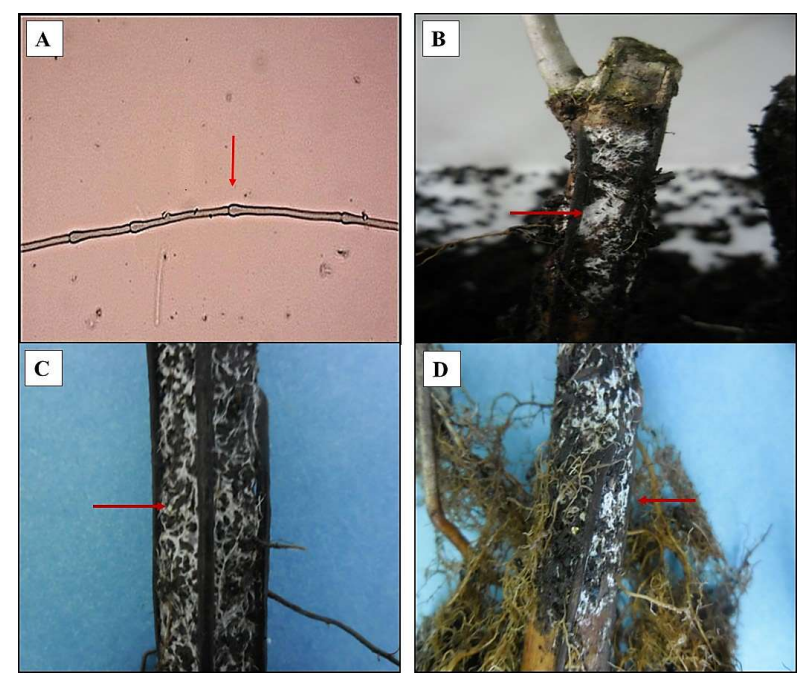

Figure 4 - A) Hyphae of Rosellinia bunodes with piriform septa (red arrows) at 400x amplification. B and C) Rhizomorphs of $R$. bunodes (red arrows) on inoculated poplar seedlings stem collar. D) Rhizomorphs of $R$. bunodes (red arrows) on the roots of inoculated poplar seedlings. Colombo (PR), Brazil, 2014.

Figura 4-A) Hifa de Rosellinia bunodes com septos piriformes (setas vermelhas) em aumento de 400x. B e C) Rizomorfas de R. bunodes (setas vermelhas) na região do colo de plantas de álamo inoculadas. D) Rizomorfas de R. bunodes (rizomorfas) (setas vermelhas) nas raizes de plantas de álamo inoculadas. Colombo (PR), Brasil, 2014.

Rosellinia bunodes shows rapid root colonization capacity as verified in this study, since root rot symptoms became internally visible at $7 \mathrm{DAI}$, while the symptoms of chlorosis associated with wilt in the aerial part appeared from 14 DAI. The speed with which this pathogen is installed in the root system of hosts and the rapid colonization of conductive tissues, compromise the xylem flow and the transport of sap to the aerial part of plants, causing their premature death. In areas near the collar, wood tissues had pigmentation ranging from light brown to black, which characterizes the internal symptoms of the disease.

The presence of sexual and asexual reproductive structures in $R$. bunodes was not observed in this study. In rubber and cocoa plants, the imperfect form of $R$. pepo (Dematophora sp.) was detected in the state of Bahia (Brazil), but without verifying the appearance of the teleomorphic phase (perithecia) in the field (Oliveira 
et al., 2008). The morphological characterization for the identification of Rosellinia spp. species are based on the shape and size of perithecia. However, teleomorphism is relatively difficult to perform under natural field conditions and in artificial culture media (Hoopen and Krauss, 2006). In these cases, pathogen identification is possible through the use of molecular biology tools (Santos et al., 2017).

The information obtained in this work will serve as a basis for future research such as epidemiological studies, identification of adequate control measures and other tests in which the determination of the physiological characteristics of the pathogen and the symptoms of the disease are necessary.

\section{CONCLUSIONS}

a) The conditions most favorable to mycelial growth of $R$. bunodes were observed in potato-dextrose-agar (PDA) culture medium at $24^{\circ} \mathrm{C}$.

b) The internal darkening symptom of the stem and the first signs of $R$. bunodes (mycelium and rhizomorphs) were observed at 7 days after inoculation.

c) Chlorosis and wilt symptoms were visible from 14 days after inoculation.

d) The presence of hyphae with pyriform septa typical of the pathogen was verified, and sexual and asexual reproductive structures of $R$. bunodes were not observed.

\section{ACKNOWLEDGMENTS}

To the Coordination for the Improvement of Higher Education Personnel (CAPES) and the National Council for Scientific and Technological Development (CNPq) for granting the scholarship.

\section{REFERENCES}

Auer G, Grigoletti A Jr. Doenças registradas em Araucaria angustifolia e Pinus spp. nos estados do Paraná e de Santa Catarina. Colombo:

EMBRAPA-CNPF; 1997.p. 3.

Bermudez M, Carranza-Morse J. Estado anamórfico de Rosellinia bunodes (Berk. e Br.) Sacc y Rosellinia pepo Pat. (Ascomycotina: Xylariaceae). Biologia Tropical. 1992;40(1):43-6.

Revista Árvore. 2018;42(1):e420111
Castaño J. Algunas observaciones soble la "llaga negra" radicular del cafeto. Centro Nacional de Investigaciones del cafe. Chinchina: Centro Nacional de Investigaciones de Café - CENICAFE; 1953. p. 28-30.

Castro BL, Carreño AJ, Galeano NF, Roux J, Wingfield MJ, Gaitán ÁL. Identification and genetic diversity of Rosellinia spp. associated with root rot of coffee in Colombia. Australas Plant Pathol. 2013;42(5):515-23.

Dhingra OD, Sinclair JB. Basic plant pathology methods. 2. ed. Boca Raton: Crc Lewis Publishers; 1995.

Duque JP. La podredumbre negra de la raíz del cafeto. San Salvador: Centro Nacional de Investigaciones de Café-CENICAFE; 1951. p. 31-7.

Ferreira FA. Patologia Florestal: principais doenças florestais no Brasil. Viçosa: Sociedade de Investigações Florestais; 1989.

Grigoletti A Jr, Auer CG. Doenças da erva-mate: identificação e controle. Colombo: EMBRAPACNPF; 1996. p. 18.

Holliday P. Fungus diseases of tropical crops. Vol. 17. Cambrigde: Cambrigde University Press; 1980.

Hoopen GMT, Krauss U. Biology and control of Rosellinia bunodes, Rosellinia necatrix and Rosellinia pepo: a review. Crop Prot. 2006;25(2):89-107. http://dx.doi.org/10.1016/ j.cropro.2005.03.009.

Indústria Brasileira de Árvores. Relatório 2017. Brasília: IBÁ; 2017.

López-Duque S, Fernández O. Llagas radicales negras (Rosellinia bunodes) y estrellada (Rosellinia pepo) del cafeto: 2 Efecto de la humedad y $\mathrm{pH}$ del suelo en el desarrollo micelial e infección.

Chinchiná: Centro Nacional de Investigaciones de Café - CENICAFE; 1966. p. 61-9.

Mantell SH, Wheeler BEJ. Rosellinia and white root rot of Narcissus in the scilly isles. Trans $\mathrm{Br}$ Mycol Soc. 1973;60(1):23-35. http://dx.doi.org/ 10.1016/S0007-1536(73)80056-7.

May-De Mio LL, Amorim L. Doenças do álamo. Revista Floresta. 2005;30(1):139-53. 
May-De Mio LL, Ruaro L. Métodos de avaliação da ferrugem do álamo e eficiência de fungicidas no seu controle. Árvore. 2008;32(5), 837-44.

May-De Mio LL, Santos AF, Amorim L. Doenças do álamo. In: Amorim L, Rezende JAM, Bergamin A Fo., Camargo, LEA, editores. Manual de fitopatologia: doenças das plantas cultivadas. 5. ed. Vol. 2. Ouro Fino: Agronômica Ceres; 2016. p. 23-7.

Moore-Landecker E. Fundamentals of the Fungi. 4. ed. Londres: Prentice Hall; 1996.

Oliveira ML, Luz EDMN. Identificação e manejo das principais doenças do cacaueiro no Brasil. Ilhéus: CEPLAC/CEPEC/SEFIT; 2005 [cited 2016 Jan 21]. Available from: http://www.ceplac.gov.br/ Agrotropica/avulsos/livrofito.pdf

Oliveira ML, Melo GL, Niella ARR, Silva VR. Black root rot caused by Rosellinia pepo, a new disease of the clove tree in Brazil. Trop Plant Pathol. 2008;33(2):90-5. http://dx.doi.org/10.1590/ S1982-56762008000200002.

Oliveira ML. Podridão negra da raiz do cacaueiro causada por Rosellinia sp. no Brasil. Agrotropica. 1992;4:21-6.

Oliveira OS. Fungos causadores de danos em Araucaria angustifolia (Bert.). O Ktze. Revista Floresta. 1981;12(2):23-7.

Pérez-Jiménez RM. A review of the biology and pathogenicity of Rosellinia necatrix - the cause of white root rot disease of fruit frees and other plants. J Phytopathol. 2006;154(5):257-66. http:// dx.doi.org/10.1111/j.1439-0434.2006.01101.x.

Petrini EL. Rosellinia species of the temperate zones. Sydowia. 1993;44(1):169-281.

Rivera V. On root rots caused by Rosellinia necatrix and Agaricus melleus: susceptibility due to the temperature of the root environment, influence of the soil and of the nature of the wood of the plant host; methods of control. Nuovo Giornale Botanico Italiano. 1940;47(1):477-87.
Ruano-Rosa D, Navarrete MD, López-Herrera C. Ensayos de control biológico de la podredumbre blanca del aguacate.In: Anales del V Congreso Mundial Del Aguacate y Actas V Congreso Mundial del Aguacate; 2003; Granada, Málaga. Sevilla: Consejería de Agricultura y Pesca; 2003. p. 519-23.

Santos AF, Machado EB, Stanosz GR, Smith DR. Primeiro relato da ocorrência de Septoria musiva em álamo no Brasil. Trop Plant Pathol.

2010;35(1):53-53. http://dx.doi.org/10.1590/S198256762010000100009 .

Santos AF, Machado EB. Controle químico da ferrugem do álamo. Colombo: Embrapa Florestas; 2010. p. 4.

Santos AF, Thomazi H, Duarte HSS, Machado EB, Tessmann DJ. First report of root rot caused by Rosellnia bunodes on a poplar species (Populus deltoides) in Brazil. Plant Dis. 2017;101(4):642.

Silva FAS, Azevedo CAV. Versão do programa computacional Assistat para o sistema operacional Windows. Rev Bras Prod Agroind. 2002;4(1):71-8. http://dx.doi.org/10.15871/1517-8595/rbpa.v4n1p71-78.

Sivanesan A, Holliday P. Rosellinia bunodes. CMI Descriptions of pathogenic fungi and bacteria. Kew, Surrey: Commonwealth Mycological Institute; 1972.

Smith FEV. Plant diseases in Jamaica in 1929. Jamaica: Department of Agriculture; 1929. p. 19-21. Report of the government microbiologist.

Sztejnberg A, Madar IZ, Chet I. Induction and quantification of microsclerotia in Rosellinia necatrix. Phytopathology. 1980;70(6):525-7. http:// dx.doi.org/10.1094/Phyto-70-525.

Vale FXR, Fernandes EI Fo, Liberato JR. QUANT - a software plant disease severity assessment. In: Proceedings of the 8 th International Congress of Plant Pathology; 2003 feb 2-7; Christchurch. Sydney: Horticulture Australia; 2003.p. 105. 